\title{
Exertional Compartment Syndrome in Five Collegiate Athletes
}

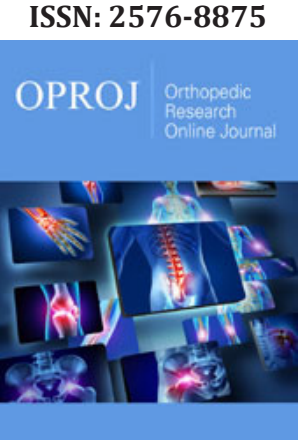

${ }^{* 1}$ Corresponding author: Suzanne E Kitts, Sport and Exercise Science Department, Gannon University, United States

Submission:

Published: 侮

Volume 5 - Issue 3

How to cite this article: Suzanne E K, Kory A S. Exertional Compartment Syndrome in Five Collegiate Athletes. Ortho Res Online J. 5(3). OPROJ.000615.2019.

DOI: 10.31031/OPROJ.2019.05.000615

Copyright@ Suzanne E Kitts, This article is distributed under the terms of the Creative Commons Attribution 4.0 International License, which permits unrestricted use and redistribution provided that the original author and source are credited.

\author{
Suzanne E Kitts* and Kory A Stauffer \\ Gannon Univeristy, Sport and Exercise Science Department, USA
}

\begin{abstract}
Five collegiate athletes (age=19.5 $\underline{1.5}$ ) suffered symptoms of exertional compartment syndrome (ECS) within the same calendar year. Two athletes suffered from unilateral ECS (anterior \& lateral), two athletes suffered from bilateral ECS (1 anterior \& lateral, 1 all four compartments), and one athlete suffered bilateral ECS (1 posterior, 1 anterior \& lateral) on two separate occasions during the year. The sports medicine staff evaluated all five athletes in the athletic training room upon complaints of lower leg pain. Athletes were referred to sports medicine physician to discuss a plan of action or obtain both resting and exercising compartmental pressures. Surgical fasciotomies were performed in three cases to release compartment pressure. ECS cases can be attributed to any one of the following issues: running surface, footwear, abnormal gait, acute direct trauma, or chronic repetitive activities. All cases in our study participated in different sports, practiced or competed on different surfaces, and were not at the same time period of the competitive year. The only common theme was that all athletes who suffered from ECS were either enrolled as freshmen/sophomore standing or transfers from other universities. Sports medicine practitioners and coaching staffs must recognize that this injury is prevalent in young collegeaged athletes who are not accustomed to increased workloads. A more concerted effort must be taken to ensure adequate time allotment for young athletes to properly adapt to the increased physical demands places on their bodies.
\end{abstract}

Keywords: Exertional Compartment Syndrome (ECS); Millimeter of mercury (mmHg)

\section{Introduction}

The etiology for Exertional Compartment Syndrome (ECS) can be described as increasing pressure within the lower leg compartments that with exertion can impede venous circulation $[1,2]$. This increased pressure can cause ischemia, pain, cramp-like feeling, and neurological deficits such as tingling or numbness to the rest of the peripheral distribution [3]. Although the physiological origin of ECS still remains unclear, the focus remains on multilayered effects of intrinsic/extrinsic forces on anatomical structures. Factors such as bony anatomy (leg length discrepancy) are considered intrinsic and imbalances in flexibility/strength or training demands are considered extrinsic [1]. The addition of contributing outliers such as compartment fascial thickness, increased muscle volume, and decreased venous return creates a perfect storm for injury to develop [1,4].

Diagnosis should be made after a full medical and health history is taken. Flick and Flick [5] explain that diagnosis of ECS proves to be difficult as there are no clinically established criteria for diagnosis. Differential diagnoses such as Medial Tibial Stress Syndrome (MTSS), peroneal nerve entrapment, periostitis, anterior tibialis contusions, and stress fractures of tibia need to be ruled out $[5,6]$. Therefore, delays in early diagnosis and treatments can be detrimental to the athlete as symptoms increase and the possibility of irreversible nerve/ tissue impairment is present. Moreover, it has been found that there can be a 22-month delay in diagnosis due to athletes' self-limiting or modifying activity based on pain, which can hinder the diagnostic process $[4,6]$.

Once diagnosis is made, the treatment plan is equally important for the athlete to achieve best positive outcomes, whether it is to treat conservatively or with surgical intervention. Conservative rehabilitation can range from a couple weeks to months; rest, assessing footwear/biomechanics, and altering activities can be included [7]. Unfortunately, there are few reports of positive outcomes with conservative treatment plans [1]. Surgical management 
via fasciotomy is considered when intracompartmental pressures surpass normal compartment standards: normal pressure is 0 to $<10 \mathrm{mmHg}$ and resting pressures exceeding $15 \mathrm{mmHg}$ or $1-2$ minutes post-exercise $>30 \mathrm{mmHg}[1,2,8]$.

\section{Reported Pressures and Treatments}

The review of five collegiate athletes (age $=19.5 \pm 1.5$ ) who suffered symptoms of ECS within the same calendar year. Two athletes suffered from unilateral ECS (anterior \& lateral), two athletes suffered from bilateral ECS ( 1 anterior \& lateral, 1 all four compartments), and one athlete suffered bilateral ECS (1 posterior, 1 anterior \& lateral) on two separate occasions during the year. Unknown factors that were not reported were footwear choices, pre-existing injuries, and biomechanical issues. The uniqueness of this cluster of ECS injuries at the university was the randomness between athletes.

1. Four females and one male athlete made up the examined group.

Table 1: Reported athlete compartment pressures and treatments.

\begin{tabular}{|c|c|c|c|}
\hline & Resting Pressure & Post Exercise Pressure & Resolved Pressure \\
\hline Patient \#1_1 & $\begin{array}{l}\text { R - Anterior (36mmHg) } \\
\text { R - Lateral (19mmHg) } \\
\text { L - Anterior (35mmHg) } \\
\text { L - Lateral (18mmHg) }\end{array}$ & $\begin{array}{l}\text { R - Anterior (68mmHg) } \\
\text { R - Lateral (34mmHg) } \\
\text { L - Anterior (45mmHg) } \\
\text { L - Lateral (49mmHg) }\end{array}$ & Not reported \\
\hline Patient \#1_2 & $\begin{array}{l}\text { R - Lateral }(6 \mathrm{mmHg}) \\
\mathrm{L} \text { - Lateral }(6 \mathrm{mmHg})\end{array}$ & $\begin{array}{l}\text { R - Lateral (1min-30mmHg) } \\
\text { (5min-35mmHg) } \\
\text { L - Lateral (Abandoned test) }\end{array}$ & Not reported \\
\hline Patient \#2 & $\begin{array}{l}\mathrm{R} \text { - Anterior (22mmHg) } \\
\text { L - Anterior (No reading) }\end{array}$ & $\begin{array}{l}\text { R - Anterior (1min-6mmHg) } \\
\text { R - Deep (1min-44mmHg) } \\
\text { L - Anterior (1min-9mmHg) } \\
\text { L - Deep (1min-45mmHg) }\end{array}$ & $\begin{array}{l}\text { R - Anterior }(9 \mathrm{mmHg}) \\
\text { R - Deep (35mmHg) } \\
\text { L - Anterior (4mmHg) } \\
\text { L - Deep ( } 44 \mathrm{mmHg})\end{array}$ \\
\hline Patient \#3 & Not reported & $\begin{array}{l}\mathrm{R}-15 \mathrm{~min}-18 \mathrm{mmHg} \\
\mathrm{L}-15 \mathrm{~min}-18 \mathrm{mmHg}\end{array}$ & Not reported \\
\hline Patient \#4 & $\begin{array}{c}\text { Conservative Treatment } \\
\text { No results reported }\end{array}$ & & \\
\hline Patient \#5 & $\begin{array}{l}\text { Conservative Treatment } \\
\text { No results reported }\end{array}$ & & \\
\hline
\end{tabular}

\section{Conclusion}

ECS injuries can be attributed to many issues: running surface, footwear, abnormal gait, acute direct trauma, or chronic repetitive activities. In the presented case, five individuals were diagnosed with ECS within one academic year. Upon examination, the one common factor that all the student-athletes shared was class standing at the university. All five students were either freshman or a transfer sophomore to the university and their respected sport.
2. Five different sports were played: females (softball, volleyball, soccer, and lacrosse) and male (cross country).

3. Five different training surfaces were used: multifunctional composite surface, traditional hardwood surface, SportTurf synthetic grass, and a combination of street surfaces and natural grass for cross country training and competitions.

4. Four athletes were in-season and one was out of season at onset of ECS.

5. Three cases (all female) needed surgical fasciotomies to release compartment pressure.

6. Two cases (one female and the male athlete) were treated conservatively with rehabilitation.

The only common factor that was found between the athletes was that they all reported being freshman or sophomore standing at the university. One of the female athletes transferred as a sophomore from a Junior College before the season started (Table 1).
When gathering the athlete's history, it was determined that the student-athletes experienced an increase in exercise intensity and volume when they transitioned from high school and/or Junior College athletics. As previously discussed, exercise intensity and volume can be a contributing factor in the development of ECS. A more concerted effort may be needed to ensure adequate time allotment for young athletes to properly adapt to and recover from the increased physical demands places on their bodies. 
Continued research and study is needed to develop a clinically sound criterion that can be used for diagnosis of ECS. Collecting a comprehensive health/activity history, considering anatomical structures, and assessing possible intrinsic and extrinsic factors can direct the possible diagnosis. In addition, reducing the time to diagnosis could decrease the possibility of irreversible nerve/tissue impairment and increase the likelihood for a more timely recovery.

\section{References}

1. Schubert AG (2011) Exertional compartment syndrome: Review of the literature and proposed rehabilitation guidelines following surgical release. The International Journal of Sports Physical Therapy 6(2): 126141.

2. Edmundsson DS, Toolanen GL, Sojka P (2007) Chronic compartment syndrome also affects nonathletic subjects: A prospective study of 63 cases with exercise-induced lower leg pain. Acta orthopaedical 78(1): 136-142.
3. Wilder RP, Magrum E (2010) Exertional compartment syndrome. Clinics in Sports Medicine 29(3): 429-435.

4. Tucker AK (2010) Chronic exertional compartment syndrome of the leg. Curr Rev Musculoskelet Med 3: 32-37.

5. Flick D, Flick R (2015) Chronic exertional compartment syndrome testing. Extremity and Joint Conditions 14(5): 380-385.

6. Bresnahan JJ, Hennrikus WL (2015) Chronic exertional compartment syndrome in a high school soccer player. Case Reports in Orthopedics, pp. 1-5.

7. Edwards PH, Wright ML, Hartman JF (2005) A practical approach for the differential diagnosis of chronic leg pain in the athlete. The American Journal of Sports Medicine 33(8): 1241-1249.

8. Young PY (2009) An unusual diagnosis for persistent leg pain in an adolescent girl. Journal of the American Academy of Physician Assistants 22(1): 31-34.

For possible submissions Click below: 